\title{
Indonesian gestures on the cover of fashion magazines
}

\author{
D.W. Soewardikoen \& M. Tohir \\ Telkom University, Bandung, Indonesia
}

\begin{abstract}
Fashion magazines published in Indonesia were initially influenced by the local culture with regard to race, gestures, and modest clothing. Nowadays, both domestic and foreign magazines are published in Indonesia. There are many similar cover designs especially in relation to layout, typography, colors, illustrations, and in the way models are displayed. This similarity is the result of globalization that continues to grow, especially ideology in the field of fashion that has been disseminated through magazines from international publishers who have contributed to the changing views and values of Indonesian society. The research question was whether there are magazine covers that still feature Indonesian gestures. The research was done through observations, literature studies, interviews, and questionnaires, looking at the origin of magazine publishing and the visual elements displayed. It was found that gestures have been influenced by norms and fashion developments. Foreign magazine covers are very influential in the development of magazine covers in Indonesia.
\end{abstract}

Keywords: Indonesian, gestures, fashion, magazines

\section{INTRODUCTION}

Various magazines published in Indonesia have been hit by media disturbances, marked by a decrease in sales turnover and a decrease in advertising revenue, especially in print media. The digital revolution gives users previously unimaginable access to new products and ideas (Cooper 2017). Publishers started to build communities to maintain their audience, and online media and social media became alternatives so that magazine publishing would not disappear altogether (Bachdar 2018). There are several foreign fashion magazines still present on the market, featured in the general magazine sales area. Domestic publishers no longer have a monopoly on fashion magazines. In fact, international publishers have begun to dominate magazine display racks in supermarkets. Transnational corporations, cyber technology, and electronic mass media have given birth to a network of closely related networks that are covering the world (Rabine 2016). Fashion has become an arbitrary force because it can determine which clothes are still suitable for use and which are out of fashion. Fashion magazines are important reading for fashion followers or the middle class who don't want to be considered out of date.

The magazine cover plays an important role for potential readers because the outermost appearance of a magazine contains headlines, body copies, and captions of images or photos, which play a role in persuading prospective magazine buyers. Cover images carry values that shape the tastes and insights of consumers. Persuasion occurs when there is a relationship between the appearance of the cover and the consumer's insight. Circulation of well-known fashion magazines from foreign publications, that carry the values of their home countries, will influence readers' tastes and insights. Consumption is not only done by buying clothes in stores but also by reading fashion magazines (Alexandersson \& Matlak 2017). Continuous development, especially ideology in the field of fashion, which is disseminated through international publications helps change the views and values of Indonesian people. This research questioned the presence of magazine covers in Indonesia that still display Indonesian gestures. 
Two similar writings on magazine covers have been published in 2018. The first publication titled Desain Cover Majalah Cosmogirl Indonesia was written by Thalia and Franzia (2018). Their focus were on the covers of Cosmogirl Indonesia Magazine published between 2015-2017. The aim of the writing was to find out the meaning contained in the cover of a Cosmogirl Indonesia magazine in informing the lifestyle of adolescent girls. Analysis of the data in the study used the Roland Barthes semiotic analysis model. The second publication titled Representasi Model Remaja Wanita dan Interaksinya dengan Model Remaja Pria pada Cover Majalah Gadis was written by Sunyoto et al. (2018). The research looked at aspects of the trick effect, pose, object, and linguistic meanings behind the sentences on the cover. The data was also analyzed using the Barthes semiotic analysis model. The two publications aimed to find out the visual meanings contained in the covers of magazines and rubrics by using a semiotic analysis approach.

Visual representation (illustration or photography) has the power to attract attention directly and has a large influence on the role of persuasion, compared to just relying on the strength of the text (Soewardikoen 2015). Gestures are a form of nonverbal communication carried out with the attitude of the body and limbs. Movements, made by body parts to express meaning, emotion, or communicate instructions, are actions aimed at expressing feelings or emphases (Navarro 2014). Body language makes observers able to see far beyond the words spoken and understand the message without hidden words conveyed. In summary, body language speaks louder than words (Borg 2009). Visual elements are focused on the models who are being displayed. There are several elements' categories, namely race, clothing, and gestures. In terms of race, it is divided into three categories: namely European, Indonesian, and Malay (Suwardikun 2017). In Indonesia, there is also Law number $44 / 2008$ which regulates pornography and the appearance of clothing openness. The percentage of openness is categorized as follows: if the entire body is not covered then the clothes are included in the $100 \%$ openness category; if the body is closed only in vital parts such as the breasts and genitals, it is included in the $75 \%$ openness; if the body is covered in the breast, abdomen, and genitals, it is included in the 50\% openness; and finally, if the body is covered from the breasts to the knee, it is included in the 25\% openness (Apsari \& Widiatmoko 2010). The openness of clothing is important to discuss, because open clothing or minimal clothing is a Western habit, while Indonesian women's clothing nowadays tend to be covered.

\section{RESEARCH METHODS}

This research used visual communication research methodology (Soewardikoen 2019), with the conceptual approach of a visual work consisting of three aspects: the visual work itself, the aspect of the creator's work, and the aspect of the viewer. Each aspect used a separate data collection instrument. Data from the aspect of visual works used observation instruments, data from aspects of the work of the creator used interview instruments, and data from aspects of the viewer used a questionnaire. Data analysis used matrix comparison analysis and a conclusion drawing matrix. The object sampled in this study was the cover of fashion magazines published in Indonesia on the magazine display racks in both supermarkets and train stations. Five samples were selected, namely Femina, Kartini, Bazaar, Vogue, and Cosmopolitan. The visual sampling for the magazines were carried out in 2017. Observations, in this case, are studies and records of magazine cover samples carried out with the theory of visual communication design. The photo aspect of the model was analyzed using gesture theory, clothing openness, and racial stereotypes. The distribution of questionnaires with random sampling criteria to 100 respondents was done through online Google Forms to female viewers as young adult magazine readers between the ages of 20-30 years. Interviews were conducted with magazine designers and fashion designers. The analysis was done by comparison matrix analysis.

\section{RESULT AND DISCUSSION}

The aspect of visual work, as mentioned above, were visual samples from covers of fashion magazines circulating in Indonesia in 2017 presented on the display racks of magazine sellers, both 
in supermarkets and train stations. The magazines analyzed were Femina, Kartini, Bazaar, Vogue, and Cosmopolitan. The covers of the Indonesian-language Kartini magazine featured models of the Malay race with light brown skin and a pose that tended to be formal with faces looking straight head and smiling. The models wore clothes with openness of less than $25 \%$. The cover of the Indonesian-language Femina magazine featured a model of the Malay race with light brown skin, a face looking straight ahead and smiling with formal body posture, and although the model wore shorts her thighs were hidden. The cover of a mixed Indonesian language Cosmopolitan magazine featured a European race model with white skin, a charming attitude with a straddling thigh position, with $50 \%$ openness of clothes, no smiling face, sharp eyes, and a slightly sloping face. Another cover featured a model with shorts showing her thighs, facing forward, with lips slightly open but not smiling. Bazaar magazine featured a European race model with pink hair, a seductive face, no smile, being embraced by another model with $50 \%$ open clothes. Another Bazaar cover showed a European race model dressed in fancy clothing with a body posture showing off her armpits. The cover of the English-language Indonesian Vogue magazine featured a European race model in a standing position pulling on a belt, unsmiling face with lips slightly open, and transparent clothing that was at $40 \%$ of openness. Another Vogue cover featured an Asian model who was swaying, and even though she was fully dressed up top, her thighs were expose. The findings from the five magazines, specifically those displayed on magazine shelves, were their font headlines used modern serifs, with only one still using special Indonesian-style fonts. Three of the five magazines displayed more than $50 \%$ clothing openness, three magazines featured attractive model poses, and three magazines used Indonesian-English mixed languages. Two magazines originating from Indonesia still used Indonesian models. One featured a model with polite gestures, of the Malay race, and an openness of less than $25 \%$. They also still use Indonesian visual elements, while Western magazines used Western visual elements and Western gestures.
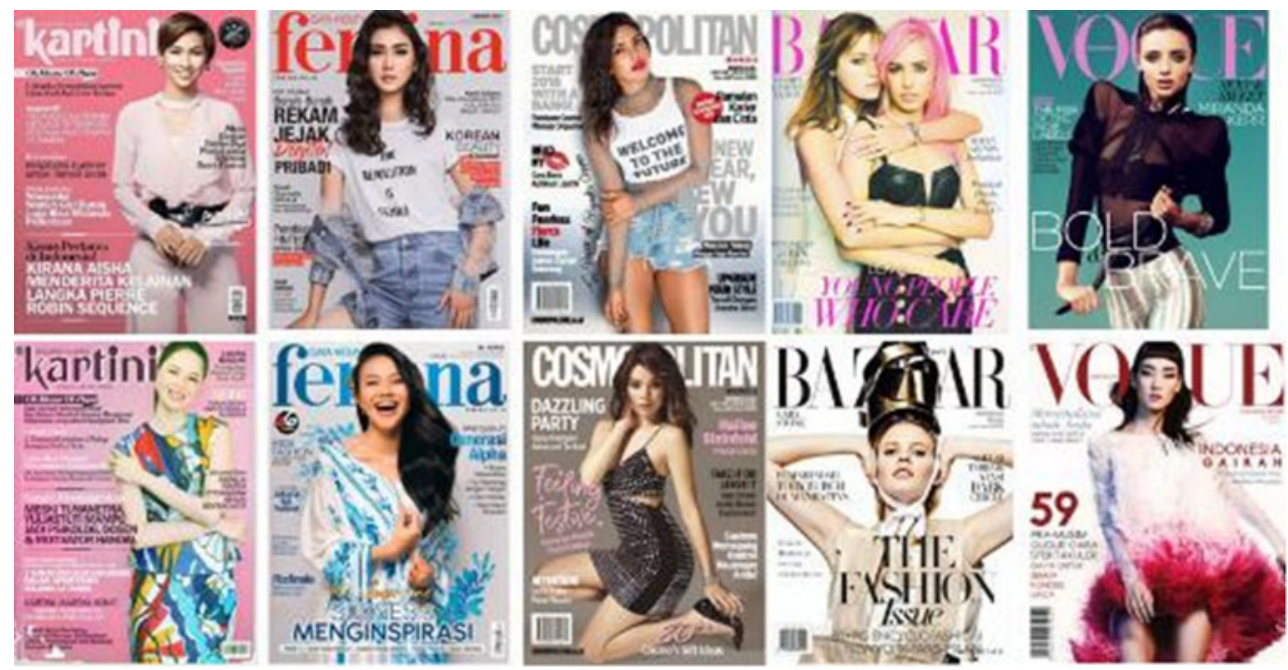

Figure 1. Cover samples of fashions magazines-Kartini, Femina, Cosmopolitan, Bazaar, and Vogue. (Source: Laporan Penelitian Unsur Visual Indonesia dalam Sampul Majalah Mode ; Suwardikun and Tohir 2019).

The following discussion is on the aspect of a creator's work. To understand how magazines make cover designs, data is required from the aspect of the creator, in this case represented by graphic designers and fashion designers. Eka Audria Wulandari is a graphic designer who worked in magazine publishing. According to interview with her, it was revealed that the cover of the magazines reflected the content and acted as the main attraction to potential consumers who might want to buy the magazines. Colors for the fashion magazine were not always the same because they 
were usually adjusted to what the magazine wanted to expose. Usually, every magazinehad its own concept so that there were no colors that were identical to other magazines. The differences in cover design depends on the desired age of the consumers; if adults like Cosmopolitan, the model would look sexy, but for teenagers the model usually stood in a normal pose. Foreign magazines are still influential but only as a reference and as examples of magazine designs in Indonesia. Faradillah Nursari, a fashion designer and lecturer in crafts and fashion, $\mathrm{s}$ that the gesture of her magazines usually highlighted on the body to the head. The development of fashion magazine covers has changed for several decades. Gestures are influenced by norms and the development of fashion in that respective era. The cover of foreign magazines is very influential in the development of magazine covers in Indonesia. It is for the reason that there are several foreign fashion magazine franchises that are usually given a template from the magazine's central company. This trend is also very influential because foreign trends are still a benchmark for trends in Indonesia.

The next aspect is aspect of the viewer. The questionnaire used for this research was distributed to 100 respondents, especially women with age ranges between 20 and 30 years old from middleand upper-middle socioeconomic status. The results obtained are as follows - the first thing noticed when seeing the magazine cover: $42.7 \%$ model; brand magazine $17 \%$; magazine content $14.6 \%$; illustration $13.4 \%$; typography $6.1 \%$; and other $2.4 \%$. Cover magazines that look more attractive: foreign magazine covers $90.2 \%$; and Indonesia magazine cover 9.8\%. Cover design affects the interest to buy: Yes $84.1 \%$; No $15.9 \%$ (Suwardikun and Tohir 2019). Some takeaways from this data are: the cover model more of a significant attraction than magazine content; foreign magazine covers are more interesting than Indonesian magazine covers; and a magazine cover affects the interest to buy.

A summary of three aspects are discussed next. On the aspects of model's race, Kartini and Femina magazines always feature Malay race models. In the meantime, Cosmopolitan, Bazaar, and Vogue magazines use European models and text with European typography. On the aspects of gesture, Kartini magazine displays models with formal gestures, Femina magazine displays models with semi-formal gestures, while other magazines from abroad display models with alluring gestures. On the clothing aspect, Kartini and Femina magazine models wear clothing with only $25 \%$ openness, while Vogue magazine displays models with about $50 \%$ openness, and Cosmopolitan and Bazaar magazines display models with open fragments greater than $50 \%$. On the aspects of language, Kartini and Femina magazines always use Indonesian, while other magazines use mixed languages, Indonesian and English. Based on the assessment, Kartini magazine has the most visual element of Indonesia. Femina appears to be influenced by outside magazines but is still of great value. Cosmopolitan and Bazaar magazines use visual elements that are lacking in Indonesia. The cover of foreign magazines as a world trend is used as an example of magazine designs in Indonesia. Franchise magazines use original visual standards from their place of origin. Foreign magazine covers are more attractive than Indonesian magazine covers, and magazine covers affect buying interest.

\section{CONCLUSION}

The world of fashion is a Western cultural industry which is disseminated through various media, as a result of global values that ultimately shift local values. Indonesian fashion tastes have influenced visual magazines since the circulation of Western fashion magazines in Indonesia. Even though Indonesian magazines have tried to maintain their existence, they are already exhausted. This is seen by the Indonesian fashion magazines that have gone out of business, while Western magazines are still circulating in Indonesia. Magazines originating from Indonesia still use some visual elements of Indonesia, while Western magazines use Western visual elements and Western-style gestures. The covers of foreign magazines are very influential in the development of magazine covers in Indonesia. 


\section{ACKNOWLEDGMENT}

Thank you to the resource person, Ms. Eka Audria Wulandari, and Ms. Faradillah Nursari for providing useful data. Thanks to PPM Telkom University for providing internal funding for this research.

\section{REFERENCES}

Alexandersson E. and Matlak R. 2017. Cultural Differences in Fashion Magazines: Targeting Vogue. University of Boras. Available at: https://www.diva-portal.org/smash/get/diva2:1143856/FULLTEXT01.pdf.

Apsari, D. and Widiatmoko, D. 2010. Visualisasi Wanita Indonesia dalam Majalah Pria Dewasa. Visual Communication Journal Wimba. Available at: http://journals.itb.ac.id/index.php/wimba/article/download/10885/40 71 (Accessed November 11, 2019).

Bachdar, S. 2018. Bagaimana Femina bertahan ditengah disrupsi media. http://marketeers.com/. Available at: http://marketeers.com/bagaimana-femina-bertahan-di-tengah-disrupsi-media/.

Borg, J. 2009. Buku Pintar Memahami Bahasa Tubuh. Think. Available at: https://books.google.co.id/books/ about/Buku_pintar_memahami_bahasa_tubuh.html?id=ts67YgEACAAJ\&redir_esc=y.

Cooper, L. 2017. '00s at FASHION: How Globalization Changed Fashion. Available at: https:// fashionmagazine.com/style/00s-fashion/.

Navarro, J. 2014. Cara Cepat Membaca Bahasa Tubuh. Change Publication.

Rabine, L. W. 2016. Globalization and the Fashion Industry. fashion-history.lovetoknow.com. Available at: https://fashion-history.lovetoknow.com/fashion-clothing-industry/globalization-fashion-industry.

Soewardikoen, D. W. 2015. Visualisasi Iklan Indonesia Era 1950-1957 Edisi 2. 1st edn. Yogyakarta: Calpulis. Available at: http://calpulis.com/index.php/products/978-602-73097-0-8/.

Soewardikoen, D. W. 2019. Metodologi Penelitian Desain Komunikasi Visual. Yogyakarta: PT. Kanisius.

Sunyoto, F.W., Natadjaja, L., and Yuwono, E. 2018. Representasi model remaja wanita dan interaksinya dengan model remaja pria pada cover majalah gadis. Jurnal DKV Adiwarna 1(6):14. Available at: http://publication.petra.ac.id/index.php/dkv/article/view/3185.

Suwardikun, D. W. and Tohir, M. 2019. Laporan Penelitian: Unsur Visual Indonesia dalam Sampul Majalah Mode. Bandung.

Suwardikun, D. W. 2017. Wajah Indo dalam Iklan Tahun 1950an. Panggung. doi: 10.26742/panggung.v26i2.171.

Thalia, R. P. and Franzia, E. 2018. Desain cover Majalah Cosmogirl Indonesia. Jurnal Dimensi DKV Seni Rupa Dan Desain 3(1):15-30. doi: 10.25105/JDD.V3I1.2845. 